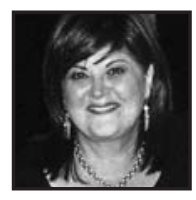

\title{
Terms of Engagement: A Question of Synergy
}

\section{Edwina Grossi, Embury Institute for Teacher Education}

\section{ABSTRACT}

This paper draws on my Ph.D thesis, An ordinary teacher: An autoethnography, which is a teacher self-study where I revisit my experiences in the field of education. Through the use of stories I explore personal experiences to come to a deeper understanding of myself, and my practice, allowing others to reflect on theirs. The article discusses the meaning of lived experience and and the terms and synergies pertaining to student and teacher engagement.

\section{ENGAGED?}

They asked me why

I dropped out of school

No love, no caring

Known as a fool

They asked me why

Grades I could not attain

Was it really me to blame?

Did you see me

Did you care

Could I not have had a share

Sat on the outside

Cold on the inside

Engaged?

With whom and what and where? 


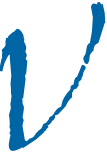

ibert and Shields (2003, p. 237) argue for a "transformative pedagogy" concerning student engagement; Ellyard (1998, p.64) refers to the development of a "new pedagogy" and Butler- Kisber and Portelli (2003, p. 2) contend that a critical perspective of engagement is needed to enhance social justice and academic excellence. So, how do we achieve this? How do we create a new, transformative, engagement pedagogy that ensures social justice and academic excellence? In my dissertation, An ordinary teacher: An autoethnography, themes concerning student and teacher engagement unfolded from the stories relating to my experience as teacher, principal, lecturer and entrepreneur. In this article I explore the following themes: i) Boring balance; exhilarating engagement ii) Are we engaged? iii) Do I touch your heart?; iv) People skills versus emotional disengagement; and v) Engaging threads. I use excerpts from my autoethnography to contextualize this discussion. It is my hope that these themes build upon each other to create a synergistic picture of student engagement.

In my career as educator, I have had the privilege of founding five different educational institutions. Drawing on this experience I suggest there is an analogy between good teaching practice, which will enhance engagement, social justice and academic excellence, and good business skills. My experiences have contributed to my self-actualization and resonate with hook's statement that "Engaged pedagogy means that teachers must be actively committed to the process of self-actualization that promotes their own well-being if they are to teach in a manner that empowers students" (1994, p. 15).

The idea behind engagement theory is that learners should be engaged in meaningful learning tasks during interaction with others (Kearsley \& Schneiderman, 2007 , p. 1). Tomlinson (2002, p. 9) suggests that engagement concerns establishing an environment which entices students to learn, and identifies five relevant criteria, namely affirmation (students feel accepted and cared for), contribution (each learner senses he/she is important enough to contribute and make a difference), purpose (each student considers that the work is interesting and significant), power (each student deems that the work will contribute to continued growth) and challenge (each student believes that although the work stretches him/her, it is not beyond his/her ability to be successful). Shernoff, Csikszentmihalyi, Schneider \& Shernoff (2003, p. 3) suggest that student engagement is influenced by phenomenological, instructional, teacher, individual and school factors. More simply, Whitaker (2004) states "Touch the heart, then teach the child" (p. 120). My school motto, Love Conquers All, concurs with this. Two stories from my thesis support Whitaker's perspective and illustrate how when a child feels loved, accepted and cared for engagement is enhanced and a foundation is laid for academic excellence. 
Karen's Story

Karen, a motivated learner who thoroughly enjoyed learning to read and receiving new books, was forced to remain at home due to a bad case of chicken-pox. Knowing the effect of being 'behind' in reading would have on her, I visited her home daily after school, taking with me flash cards of new words I had made especially for her and the books in which they appeared. Being an enthusiastic learner, it did not take long for Karen to learn the new maths concepts as well.... I knew Karen would have returned to school very demotivated and quite 'lost' had I not spent this special time with her (Grossi, 2006, p. 71).

\section{Melanie's Story}

Melanie had a genuine love for young children and was an eager student teacher. During a lecture on 'unconditional love for each pupil,' I demonstrated to each student the power of a hug. As I hugged the first student, Melanie, seated in the third row, blushed and asked to be excused. I sensed something was amiss but carried on hugging each student. When Melanie returned I was waiting for her. 'Please Mrs Grossi, don't hug me,' she said. 'Why, my darling?' I asked. 'Just don't. Please-I beg you-just don't,' she answered.'Melanie, how will you be able to hug little children or their mothers if you can't hug me?' I asked.'Mrs. Grossi you don't understand. My mother died when I was two. My father and stepmother have never hugged me or touched me in any way,' she said.'Melanie, I love you,'I said, as I enfolded her stiff body in my arms. Slowly but surely her muscles began to relax as she sobbed and let go of her pain. We stood hugging and crying for what seemed like hours. There was not a dry eye in that room. From that day Melanie hugged me every morning and I was moved to tears as I observed little children running up to her for a hug. One day her eye caught mine as a little head lay nestled on her shoulder, comforted by her arms. As she lifted her head from his, our eyes met and the unspoken message seemed to be, 'Thank you for helping me release my power to love and be loved' (Grossi, 2006, p.139). Great educators understand that behaviours and beliefs are tied to emotion, and they understand the power of emotion to jump-start change (Whitaker, 2004, p. 121). 


\section{Boring Balance; Exhiliarating Engagement}

Having been involved in many entrepreneurial projects and confronted many problems, it has been my experience that in times of challenge new approaches are required to resolve a chaotic situation. It was in these situations, when I had to be totally engaged with people and problems, that my biggest personal growth, socially, emotionally and academically, took place. Csikszentmihalyi (1990) speaks of flow theory, which happens when people are stretched to their limits to meet challenges (Shernoff et al., 2007, p. 5). The authors explain that flow happens when a person is deeply absorbed in a challenge and functions at her optimum capacity. The experience itself becomes the reward.

The business world demands a new language - a language which uses terms such as "networks," "alliances," "culture" and "shared values" (April, Macdonald \& Vriesendorp, 2005, p. 25), and I argue that the same should apply to the teaching profession. Now, could I add chaos theory to the combination of the "new language" within the framework of Csikzentmihalyi's (1990) flow theory? As Galbraith (2004) suggests:

The new science of chaos has alerted us to the butterfly effect, to the very considerable impact tiny fluctuations in a non-equilibrium system can have on its output (p.3).

Out of chaos comes order, new ways of thinking and new growth as we engage with a challenge, seek advice from others and stretch ourselves to the limit. However, Galbraith (2004) advises that in order to be successful, the leader, or the teacher, needs to first address culture “...destroying old myths, stories, legends ... and where appropriate creating new ones" (p.3). When a positive outcome emerges from the chaos, it results in feelings of camaraderie, exhilaration and maturity. Self-worth and respect for others are enhanced and one is spurred on to accept and conquer more challenges. Therefore, by looking at student engagement with new eyes, one realizes that balance is boring and does not allow for growth and engagement, whereas turbulence is "thrilling" and paves the way for optimum growth in all areas (April et al., 2005, p.19).

Could one therefore suggest that one way to create student engagement leading to social justice and academic excellence, as suggested by Butler-Kisber and Portelli (2003, p. 2), would be to create a kind of "chaos," or disequilibrium? There is nothing like turbulence to "throw" people together and produce the greatest learning 
and engagement with others. I have found the famous words of John Donne, "No man is an island," quite true.

Wheatley (1992, p. 199) believes that the movement towards participation, engagement and collaboration in the workplace is rooted in chaos theory. The greatest breakdown of barriers between people, whether teachers or students, occurs when they become interdependent. Maxwell (2004, p. 229) states that, "As long as ... people experience consistent wins in areas they value, they develop synergy." Therefore, if it is our job as teachers to ensure engagement, growth, creativity, new approaches to problems, academic excellence and social justice, then we need to prepare for a sense of chaos. Am I saying the classroom must be in a turbulent state, that the lessons must be chaotic? Indeed not! In fact, creating turbulence as I am Defining it requires even more planning and foresight on the teacher's part.

\section{Are We Engaged? Do I Touch Your Heart?}

The following excerpt from my thesis, is a fictional discussion, the only fiction in the piece, with a Grade 8 class and is meant to demonstrate that learning in school should be an active, engaging, experiential process which is meaningful, challenging, individualized (by catering to different talents and social groups) and varied. It is my belief that a teacher has the power to encourage all learners to achieve and reach their full potential by treating them as if they are already on the path. Autoethnography enables the researcher to journey back in time to recollect lived past experiences which shaped her life and to share these with an audience (Eisner, 1997, p.259). What better way to share some of my experiences relating to engagement, than by presenting them in story form? According to Ellis, $(2004$, p.23) a story makes the theory come alive. The following story represents an aggregate of many experiences I have had with students, and how I have learned from them.

Treat a man as he appears to be and you make him worse. But treat a man as if he already were what he potentially could be, and you make him what he should be.

Von Goethe (1749-1832) 


\section{Fictional Discussion With a Grade 8 Class}

"Boys and girls, I've explained the different ways people learn. We are all different-some are visual learners, others learn by hearing and yet others from experience and touch. We learn through our senses. Some people do things others find difficult and vice versa. Today l'm going to read this piece of writing to you twice. Jot down anything you want to-anything that comes to mind as I read. Remember you will all have different answers and no answer will be incorrect or of no benefit. Here we go.

G: (Mrs. Grossi) Sam, what did you get out of the piece?

S: $\quad$ (Sam) Mrs. Grossi I felt that if I were on the bus that you read about, I'd ask the driver to stop for me to take pictures of the beautiful fields of sunflowers, the olive vines and the setting sun.

G: What would you do with the pictures, Sam?

S: I think I would bring them to school to show everyone.

G: Sam, your art is so expressive ... would you consider painting the scene from your imagination?

S: Wow! I didn't think of that-I can already see it in my mind!

G: You know what I loved best? What actually framed the picture for me were the words 'the sun painting streaks of gold in the sky.'

Bo: (Boetie) Wow! Words are powerful!

Be: (Beth) Yes, because you use your imagination. Now you can see the picture.

G: Quite right, Beth. That's what we need to do when drawing, writing poetry or writing. Use the imagination and be descriptive so that the person reading your work can see the picture without having a photograph. Beth, you have a flair for words. Would you like to compose a verse using words like 'the sun, 'streaks of gold,' 'the field of sunflowers' — something like that?

Be: Do you think I can do it, Miss?

G: Why not? I loved your last poem. I've framed it and put it in the staff room.

S: (Sipho) Mrs. Grossi, you said we learn through our senses. Do you know what I heard? I heard the people in the square-the young ones laughing and the old ones whispering proudly about their grandchildren to each other. I also heard the young children asking 'Ma, where's the Nutella? I'm hungry!' Do you know I even heard their Italian accent!

G: That's excellent! Could you use that 'sense' in story-writing? 
R: (Reena) Absolutely! I'm also going to look up the Afrikaans words in the dictionary and use this scene in my Afrikaans essays as well.

S: Imagine me writing about Nutella in Zulu! (The class laughs. Sipho has such a good sense of humour. How relaxed they all seem, and so attentive. I can see they are engaged in this lesson.)

A: (Amara) I heard other things. I heard music and laughing.

G: Wonderful, Amara! So did I! Instead of writing in an essay 'the music was playing,' what could you now write? Do you remember how the author put it?

A: I'd write 'the music changed from a slow foxtrot to a tango.' That was what you read! I wrote it down.

G: This is incredible! What else?

H: (Heinrich) I've never heard of a 'tarantella.' Is it a dance? I'll look it up on the Internet.

G: Yes-in that way you'll extend your knowledge. I don't know anything about the tarantella myself. Please won't you let me read what you download? Better still, Heinrich, won't you tell us all what you've learned? Let me know when you're ready.

Ma: (Maria) I'd love to do Latin American dancing one day. I'm going to look up all the different kinds of dancing on the Internet as well.

G: Fantastic! I did a bit of dancing when I was younger and would love you to share with me and the class what you have learned, Maria. Class, do you notice what's coming out in this lesson? There is not one person in the world who knows everything - there's always more to learn! We all have talents and one talent isn't better than the other.

Y: (Yvonne) Miss, I felt a little sad that the group missed the celebration in the square.

D: That's why it's so important to check things. Don't rely on a travel agent telling you about a certain festival in Italy-look it up yourselves on the Internet. Always do your own research guys! However, Yvonne, having said that, we must realise that often things happen in life for a reason, don't dwell on what might have been-look at what is and rejoice. Maybe if they had been in time for the celebration party they would have missed the beautiful moment in the square!

Y: I think I'm going to do a study on this area in Italy and the different festivals.

G: Yvonne, I sense you would be outstanding in drama. How about organising a group to re-enact the scene for us?

Y: Cool! 
Sab: (Sabrina:) All this talk of Italy makes me hungry miss! My mother is Italian and she makes the most wonderful food, especially lasagne. I could just taste the food as you were reading.

G: Do you know how to make lasagna, Sabrina?

Sab: Yes miss. I enjoy cooking.

G: Sabrina, would you like to demonstrate to us how lasagna is made on Thursday in our life skills lesson? Can you ask the secretary to make a copy of the recipe for each of us as well? I'd love to know how to make lasagna properly. Remember, you are going to have to double or treble the recipe so that we can all have a taste! It's okay if you want to bring your mom to help. And Sam, can you take the art lesson on Wednesday? In the beginning just read the piece to the class again to refresh their memories, and maybe give a few suggestions as to colour and form. Give a choice of medium.

L: (Lieben) Well, I'm going to write a story. I want to be an author when I'm big so I'll begin with the story I already have in my mind from your reading.

G: Well done Liebs! Can you bring chapter by chapter to read to the class as you complete it? How exciting for us to be involved in a novel from the beginning. It will be a wonderful addition to our library. Imagineyou'll be the first pupil to have a book in the school library! And Liebs, will you take the creative writing lesson on Friday?

Th: (Thembe) Can I do the same as Lieben?

G: Of course! We need different inputs because no two writers write the same way and you'll bring a completely different version to the class. Now we'll have two books from this class. Wonderful!

Ti: (Timothy) Mrs. Grossi, the music also got to me! I just love music. I'd like to research different musical instruments.

G: A fantastic idea! Who'd like to do this project with Timothy? It's quite a big one. Edrich, I know you play the French horn. Won't you play for us the next music lesson? I am fascinated by this instrument.

Na: (Natasha) Timothy, I have a few instruments at home. Let's do a display table together. Maybe Edrich can add his horn to the table.

Ja: (James) Can I paint the background? I'll do a frieze of the different musical instruments!

F: $\quad$ (Faria) Can I help? I play the piano, you know.

G: I'd love to be able to play the piano one day! You need to give us a treat Faria. We have a piano in the hall.

Mi: (Mickey) Well I play the guitar.... 
G: Mickey, I didn't know you could play a guitar!

Mi: Yes, Miss.

G: Mickey, would you play for us in our next music lesson?

Mi: With pleasure, Miss. Do you know I sing as well? We have this little band ...

Mrs. Grossi surveys her class. How wonderful they are, and how exciting teaching is! How happy and motivated they all seem. There is Mickey who is experiencing a barrier to learning but plays the guitar and sings, to everyone's amazement! How proud he was when the children said 'No way! Do you really play! Cool!' Right, Mrs. Grossi thought.'Mickey, you are going to love reading —I'm going to find as many books on guitars as I can.'

G: Girls and boys, form yourself into groups; those interested in music with Mickey, those wanting to paint with Sam, those wanting to write verse with Beth, those wishing to write stories with Lieben and Thembe, those wanting to be involved in drama with Yvonne and those doing research with Heinrich.

Jo: (John) Miss....

G: Yes, John.

Jo: My cousin in Grade 10 is going to drop out of school and the family is, like, upset because he's not like, thick and all that, you know what I mean?

G: Why on earth does he not want to finish his schooling?

Jo: He says school sucks. He says learning is boring and monotonous. The teacher always shouts at him-like he makes mistakes, and he hasn't got time to do his homework properly because he has to look after and help his mom who's very ill, and things like that. Miss, I wish he could come to our school. Learning is such fun-we know we will make mistakes but it's part of learning. The way we learn is meaningful. We understand it. I mean I, we, you, the whole class is always involved in each other's learning. We help you-we teach you, you teach us-we learn from one another and we learn by researching ourselves. It's cool!

L: Yes Miss, he's right. I find learning incredibly exciting. One day I want to be a teacher, too.

B: (Bradley)Ja, then when you're old you could write a book on it! Hey! Didn't you say you want to be an author? How can you be a teacher and an author? 
L: Why can't I write about the different ways I teach and the effects on the children? Or maybe I'll write about my life in the teaching profession.

G: Lieben, that's called an autoethnography.

L: A what?

G: An autoethnography. It's about your life in a particular field. You know, I think every teacher should write an autoethnography. We all have so much to learn from one another.

G: Tamie, why are you so quiet today?

T: (Tamie:) Miss, I've heard some bad news. Can we talk at break?

G: I'll be waiting for you."

(Grossi, 2006, pp. 158-169)

Good business practices correlate with education (Galbraith, 2007, p. 2). What is needed first and foremost for success in any area is vision. Vision is akin to a "mind photograph" and links mission and action. However, vision, according to April et al. (2005, p. 19)," ...animates, inspires, transforms us only if it is deeply rooted in our human needs and values. And the essential need and value is love."

I learned that the key to all teaching is: You must love your students with a deep selfgiving love.

Russell $(2007$, p.1)

According to April et al. (2005), love is demonstrated in organizations in three ways: love for ourselves, love for others and love for what we do. The author explains further that, "... good management is largely a matter of love, because proper management involves caring for people, not manipulating them" (p. 19). Jaworski is of the opinion that the capacity for love creates a "field" surrounding a person that "transcends individual and selfish needs." Are schools not organizations? Are we hoping to create social justice and academic excellence? Then we need to learn to love others, ourselves and our work. There can be no greater satisfaction than when we do what we love and love what we do. Passion, enthusiasm and commitment are the outcomes of the love of a profession. I believe that these three elements are the key to the "how" a person teaches, and "how" a person teaches is a powerful factor in student engagement. 
And all knowledge is vain save where there is love: And when you work with love you bind yourself to yourself, and to one another, and to God.

Kahlil Gibran (1883-1931)

In romantic terms people who are in love usually want to get engaged, they are not manipulated into doing so. The word "engage" is defined in the Oxford Dictionary (Soanes, Spooner \& Hawker 2001, p. 292), as when we "enter into a contract to do," "enter into combat with" and "interlock," amongst others. Bearing this in mind, the word "engage," when used in the context of teaching, speaks to me of the contract teachers and learners enter into, a contract that binds them together as they enter into relationship, and a contract which will require learner and teacher to interlock with one another to achieve common goals. However, as in a marriage contract, this requires unconditional love and acceptance, otherwise the contract would become null and void as there would be no demonstrations of emotions, no going the extra mile, and so forth. Furthermore, learners construct their own knowledge as they engage with the world. Therefore, the primary function of the teacher is to create a warm, challenging, learning environment that will not only foster this kind of learning , but will also assist students in learning socially accepted behaviour which, in turn, lessens classroom conflicts. This is accomplished as the teacher recognizes the need for continuous student affirmation as she caters for the different learning styles, multiple intelligences, various talents and the diverse personalities of the learners in her class (Dryden \& Vos, 2005, p. 353). This in itself may seem the epitome of chaos theory to some, but allows for incredible student/task, student/teacher, student/peer engagement.

The word education is derived from the Latin word educare which means to "draw out the unique qualities of the whole person" (Dryden and Vos, 2005, p. 143). The process should also allow for learners to make decisions concerning the planning, implementing, reporting and assessing of the work (Russell, Ainley \& Frydenberg, 2007, p. 13). Zyngier (2004, p. 10), speaking of critical-transformative engagement (Vibert \& Shields, 2003, p. 237), states that "All students should be able to see themselves as represented in a curriculum that challenges hierarchical and oppressive relations that exist between different social groups." April et al. (2005, p. 87) advise that the new South African business leadership has become conscious of the multiple realities that exist in diverse groups and cultures. Similarly, in the classroom situation, in order for teachers to engage fully with each learner, they need to recognize and value that learners' perspectives differ according to their life experiences. 


\section{People Skills Versus Emotional Disengagement}

Individuals with excellent people skills connect with us easily, make us feel good about ourselves, and lift us to a higher level. Our interaction with them creates a positive experience. (Maxwell, 2004, p.xiii)

The following co-constructed story from my autoethnography demonstrates emotional disengagement and "re-engagement." Butler-Kisber and Portelli $(2003$, p.3) ask, "Why does the serious involvement of students enhance their engagement, and in what ways?" They also ask "How does the pathologizing of students that do not fall within the mainstream distract us from a more complete understanding of disengagement? What conception of engagement is consistent with an inclusive curriculum?" Perhaps the story of Nicholas, a handsome twelve-year-old child with cerebral palsy who refused to attend school, can help provide an answer.

Nicholas was not only frustrated with the fact that he had to travel miles to attend a "special school," unlike his younger brother who attended school within walking distance from their home, but also found school boring and "nonsensical." His biggest Goliath was reading. However, his greatest disappointment was that, unlike his brother, he would never be able to be involved in cricket, the sport he so dearly loved. Therefore, he decided at the age of twelve to simply drop out of school. We had never met so I invited Nicholas to tea one Saturday. This is what transpired.

E: (Edwina) Nicholas, I have a school, a place where learning is such fun that children are upset when it is holiday time. I would love you to be part of it.

Ni: (Nicholas) No, because you are going to make me read.

E: Me? Make you read? Oh no-I don't make children do anything. Children must enjoy learning.

Ni: Well, what will I do?

E: I know you love cricket. We'll follow the South African Cricket team on the map as they play all over the world. We'll look at pictures in the cricket magazines and your teacher will read cricket magazines and the newspapers to you and your friends. There is a television in one of the rooms and you will be responsible for informing the school of the score.

$\mathrm{Ni}$ You promise?

E: I'll only promise if you will allow me to show you my school today. There are a couple of empty classrooms so, if you like the school, you 
can choose your classroom. Here is a cricket magazine I bought you. Inside is an excellent colour poster of the South African cricket team that we'll pin on the wall before we leave.

Ni: Is the school far? I want to go to my brother's school-it's just near where we live.

E: Take my watch. I will drive from your house to your brother's school. Let's see which one is the closest. You will be surprised!

Ni: Will you let me play cricket like my brother?

E: And why not?

Ni: Because they say I'm different. I have cerebral palsy, but there's nothing wrong with my brain. I'm very good at math but my eyes hurt when I read.

E: We're all different in some way. Don't you think it would be a boring world if we were all the same? I'm not very good at math and you are. You don't like reading and I do. I don't know how to follow cricket and you do.

Ni: I remember all the cricket scores from every game.

E: So your memory is excellent!

Ni: So, why can't I go to my brother's school?

E: $\quad$ Because God kept you for my school. He heard when I asked Him to choose children for me. If you were at your brother's school I would never have met you - that would be very sad for me.

Ni: My brother's school sucks! " (Grossi, 2006, p. 165)

The day I cried in front of the class was the day Nicholas read me a verse he had written. He informed me of his newly found insatiable love of reading. He was completing more than three books a week! How he loved being on the cricket team! How important he felt as he donned his cricket gear in preparation for a match.

According to Maxwell (2004, p. xiv), "People skills make the difference between those who excel and those who don't" in the teaching profession. Hopkins $(2005$, p. 1) suggests there are eight essential people skills, which Coan $(2005$, p. 1$)$ likens to emotional intelligence. These are: the ability to understand people; the ability to express thoughts and feelings in a clear manner; the ability to voice concerns when needs are not being met; the ability to ask for, and give, feedback; the ability to influence others' thoughts and actions in a positive manner; the ability to deal with and resolve conflict; the ability to delegate, share and work as a team member and the ability to "walk away" from unproductive relationships. 
"Servant Leadership" is referred to in business as a "more holistic approach to work" (April et al., 2005, p. 99). The authors suggest we interpret the word "servant" to be a "nurturer of the human spirit," or an "inspirer." Syque $(2007$, p. 1) suggests there are two criteria for assessing servant leadership. The first is that the people served develop as individuals and become servant-like themselves. The second is the "extent to which the leadership benefits those who are least advantaged in society." Is a teacher a servant leader? Is disengagement in some instances the result of the human spirit not being nurtured or inspired as it should be? Could teachers become a channel for social justice?

Russell et al. (2007, p. 6) see emotional disengagement as "learned helplessness." Many learners attribute repeated failure to some inadequacy within and may simply "give up," believing that they can do nothing to change themselves or the situation in which they find themselves. All learners need challenging but attainable, meaningful tasks that allow them to build on prior knowledge and their interests. Furthermore, Brewster and Fager (2000, p.5) advocate that educators should build on intrinsic and extrinsic motivation "to engage students more fully in school." This can extend from verbal praise to trophies. However, as in the case of Nicholas, the classroom climate needs to respect individual differences and support socialconstructivist learning.

Research tells us that the teachers who are most successful in engaging students develop activities with students'basic psychological and intellectual needs in mind.

(Brewster \& Fager, 2000, p. 7)

\section{Engaging Threads}

There can be no engagement without a partnership. Traditional hierarchical principles of leadership in business are yielding to those of teamwork, involvement, community and behavior that occurs in an ethical and caring manner (April et al., 2005, p. 99). In the same $m$,teachers and learners can create a positive climate for social collaboration. Russell et al. $(2007$, p) state that:

A supportive, friendly, safe classroom, that emphasises positive emotions and interactions, contributes to students' social-emotional wellbeing, resilience, productive coping strategies and engagement in learning" (p. 14). 
The following excerpt from my autoethnography demonstrates that learners will enjoy engaging with tasks they themselves find challenging, interesting and important, without even being asked to do so.

While the school was being built, pupils were shown the plans and witnessed, among other things, borer-eaten wood being replaced, and the original tiled floor being unearthed under layers of carpet and linoleum. How wonderful it is for children to learn from experience! They enjoyed feeling the borer-eaten wood and seeing how windows are replaced, and many other incidents offered visual learning experiences. One little boy was so fascinated that, of his own accord, he did a study on borers. This proved to me once again that if a person is interested in a topic, he/she does not need to be coaxed to learn about it. What a wonderful way to teach English, Mathematics, History, and Biology, or any other subject! While searching for information and writing about borer, this child was improving his English, learning methods of research and, although young, was learning Biology! We made full use of the construction experience-Numeracy had never been more fun as we measured and estimated many things to 'help' Uncle Mickey (my husband), for example, how many pieces of new wood he would have to order, as well as the size and number of windows needed. Mathematics came alive for my Grade 1 and 2 pupils as they experienced the value of this learning area. A copy of the plans was displayed in each classroom and the boys, especially, took great delight in informing me of the progress of the building. I took equal delight in pretending to rely on their calculations regarding the time of completion of certain tasks, and the number of items that still needed to be ordered (e.g., bricks, fascia boards and tiles). The pupils were fascinated by the installation of the toilets, basins and electricity. Many declared their newfound profession for their future lives. Learning should always be meaning-based, exciting and relevant to the learner (Grossi, 2006, p. 158).

\section{Conclusion}

In the last decade, research has equated student engagement with academic success (McMahon \& Portelli, 2004, p. 1). If teachers believe in complete engagement with their students and the learning material, as well as democracy, social justice and academic excellence, then they need to rethink and perhaps reframe the concept of 
teacher to that of leader, and draw a parallel between the new landscape of business skills and the teaching profession.

I would suggest that an autoethnography is a powerful tool for engagement for both writer and reader. It brings about motivation, change and self-understanding in the writer and the reader. I transfers valuable learning material to in-service and pre-service teachers, for exploring other ways of teaching, and encourages teachers to become totally engaged with their learners and to speak out beyond the educational system. All of these dimensions were clearly evident in the results of my research. Although in the past decade there has been a growing interest in the use of the life story to facilitate teacher development (Muchmore, 2002, p. 1), it was as early as 1926 when Lindeman (p. 9) saw the value of personal, lived experience in learning and coined the phrase a "living textbook" (p. 9). This article has allowed me to open my living textbook and share some of the stories which I hope may contribute to and further the discussion on student engagement.

\section{References}

April, K., Macdonald, R., Vriesendorp, S. (2005). Rethinking Leadership. Cape Town: University of Cape Town Press.

Brewster, C. \& Fager, J. (2000). Increasing student engagement and motivation: From Timeon-task to homework. Retrieved 21 March, 2007, from http://www.nwrel.org/request/ oct00/textonly.html\#engage.

Butler-Kisber, L. \& Portelli, J.P. (2003). The challenge of student engagement: Beyond mainstream conceptions and practices. Special issue of the McGill Journal of Education, 38(2), 1-11.

Coan, G. (2005). Build your people skills. Retrieved 18 April, 2007, from http:// www.ezinearticles.com/? Build-Your-people-Skills\&id=9420.

Dryden, G. \& Vos, J. (2005). The new learning revolution. United Kingdom: Network Educational Press.

Eisner, E.W. (1997). The new fronteir of qualitative research methodology. Qualitative Inquiry, 3(3), 259 - 273.
Ellis, C. (2004). The ethnographic I. A methodological novel about autoethnography. Oxford: Rowman and Littlefield.

Ellyard, P. (1998). Ideas for the new millennium. South Carlton, Victoria: Melbourne University Press.

Galbraith, P. (2004). Organisational leadership and chaos theory. Journal of Educational Administration, 42(1) 9-28.

Grossi, E.T. (2006). An ordinary teacher: An autoethnography. Unpublished doctoral thesis. Durban: University of KwaZuluNatal.

Hopkins, L. (2005). "People Skills: Eight Essential People Skills." Retrieved April 18, 2007, from http:// www.ezinearticles.com/ People-Skills:-Eight-Essential-PeopleSkilkks\&id=12294.

Kearsley, G. \& Schneiderman, B. (2007). Engagement Theory: A framework for technology-based teaching and learning. Retrieved April 13, 2007, from http://www. home.sprynet.com/-gkearsley/engage.htm. 
Lindeman, E.C. (1926). The meaning of adult education. New York: New Republic.

Maxwell, J.C. (2004). Winning with people. Nashville:Thomas Nelson.

McMahon, B. \& Portelli, J.P. (2004). Engagement for what? Beyond popular discourses of student engagement. Forthcoming in Leadership and Policy in Schools.

Muchmore, A. (2002). Methods and ethics in a life history study of teacher thinking. Retrieved April 13, 2007, from http://www. nova.edu/sss/QR/QR7-4/muchmore.html.

Russell, J.M. (2007). Student-centered learning. Retrieved July 1, 2007, from http:// www.al.nd.edu/about-arts-and-letters/ student-centeredlearning/learning-tolove-dante.

Russell, V.J., Ainley, M., \& Frydenberg, E. (2007). Schooling issues digest: student motivation and engagement. Retrieved March 22, 2007, from http://www.dest.gov.au /sectors/school_education/publications_r esources/schooling_is.

Shernoff, D.J., Csikszentmihalyi, B.S., \& Shernoff, E.S. (2003). Student engagement in high school classrooms from the perspective of flow theory. Retrieved April 13, 2007, from http:// www. Qlrc.org/pmachine/more. php?id=10_0_1_0_M3.
Soanes, C., Spooner, A., \& Hawker, S. (2001). Oxford Dictionary, Thesaurus, and Word Power Guide. New York: Oxford University Press.

Syque (2002-2007). Servant Leadership. Retrieved April 18, 2007, from http://www. changing minds.org/disciplines/styles /servant_leadership.htm.

Tomlinson, C.A. (2002). Invitations to Learn. Educational leadership, 60(1), 6-10.

Vibert, A.B. \& Shields, C. (2003). Approaches to student engagement: Does ideology matter? McGill Journal of Education, 38(3), 221239.

Wheatley, M. (1992). Leadership and the New Science: Learning about Organization from an Orderly Universe. San Francisco: BerretKoehler Publishers.

Whitaker, T. (2004). What great teachers do differently: 14 things that matter most. New York: Eye On Education.

Zyngier, D. (2004). Doing education not doing time. Engaging pedagogies and pedagogues - what does student engagement look like in action? International Education Research Conference. Melbourne.

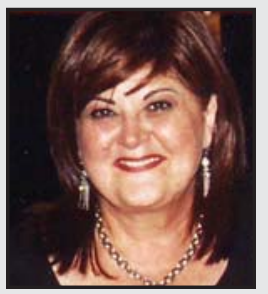

Edwina Grossi, qualified in 1965 as a Foundation Phase specialist teacher in South Africa. In her career as teacher, principal, lecturer and entrepreneur, she founded Wonderland PreSchool, Wonderland Baby Care, Embury College Private Primary School, Embury College High School, Train-a Child Pre-School Teacher Training College, and is co-founder of Embury Institute for Teacher Education which, inter-alia, offers courses to in-service teachers, and training across a broad spectrum of fields.

LINK TO:

http://www.embury.co.za/ 